\title{
Determinants of working capital management: evidence from Malaysia
}

\begin{abstract}
Working capital management is a part in firm's financial decision. Inefficient in managing it consequently affect firm value. Managers should consider all factors that affect working capital management. Therefore, this study investigates the determinants of working capital management of listed firms in Malaysia for the period 2000-2006. Cash conversion cycle is used as comprehensive measure of working capital management. Results indicate that firm size, debt ratio, growth of the company, economic growth and inflation associates with firm's working capital management.
\end{abstract}

Keyword: Cash conversion cycle; Panel analysis; Working capital management 